\title{
Birthplace, Bloodline and Beyond: How 'Liberian Citizenship' Is Currently Constructed in Liberia and Abroad
}

http://www.tandfonline.com/doi/full/10.1080/13621025.2016.1204269\#.V4R-RSMrKfQ

Robtel Neajai Pailey

International Migration Institute, University of Oxford, Oxford, UK

robtel.pailey@qeh.ox.ac.uk

\begin{abstract}
As a $21^{\text {st }}$ century post-war, emigrant-sending country, Liberia reflects global citizenship norms while simultaneously departing from them, and this unique positioning offers new opportunities to theorise citizenship across spatial and temporal landscapes. In this article, I examine 'Liberian citizenship' construction through a historical prism, arguing that as Liberia transformed from a country of immigration to one of emigration, so too did conceptualisations of citizenship-moving from passive, identity-based citizenship emphasising rights and entitlements to more active, practice-based citizenship privileging duties and responsibilities. Given the dynamic trends in citizenship configuration across the globe and particularly in Africa, this article fills gaps in the growing body of literature on citizenship and participation in emigrant-sending countries by contributing to wider debates about how identities, practices and relations between people transform in the aftermath of violent conflict. Empirical evidence presented is based on multi-sited fieldwork conducted in 2012 and 2013 with 202 Liberians in urban centres in West Africa, North America and Europe.
\end{abstract}

Keywords: Liberia; citizenship; dual citizenship; 1973 Aliens and Nationality Law; 1986 Constitution; Negro clause; Unification Policy

Word Count: 9412 (including notes and references) 


\section{Introduction}

Liberia represents a stark case study in citizenship construction because of its idiosyncratic history of black settler state formation, historical trajectory as a country of both immigration and emigration and recent intermittent armed conflicts spanning more than a decade. As a $21^{\text {st }}$ century post-war, emigrant-sending country, Liberia reflects global citizenship norms while simultaneously departing from them, and this unique positioning offers new opportunities to theorise citizenship across spatial and temporal landscapes. Although the literature on citizenship heavily emphasises analysis from immigration states, some scholars argue that an examination of citizenship construction from the perspective of emigration states, such as Liberia, is becoming increasingly vital (Barry 2006). The nature and meaning of citizenship within emigration states vary greatly from that of immigration states, as emigration states increasingly depend on the contributions of their citizens abroad, who inevitably influence the construction of citizenship norms in their countries of origin (Barry 2006, 19) and this is evidenced by the introduction in 2008 of proposed dual citizenship legislation for Liberia.

According to Barry, there are three ways in which emigrant citizens and their homeland states are reconfiguring citizenship: i) emigration states have construed emigrant citizens as heroes who contribute to the economic regeneration of the state through remittances, taxes (i.e., Eritrea and Korea), and investment incentives (i.e., India); ii) emigration states have embraced plural citizenship by amending citizenship laws, thereby allowing their nationals to retain homeland citizenship while simultaneously naturalising in a foreign country (i.e., Philippines, Turkey, Senegal); and iii) emigrants are demanding the right to participate fully in the political processes of their homelands - and being granted that right in the cases of Colombia, Peru, and Dominican Republic - although most emigration states do not permit the holding of political office or voting in general and presidential elections by nationals abroad (i.e., Mexico) (Barry 2006, 34). Nevertheless, while Barry's analysis demands new ways of thinking about citizenship, it privileges the citizenship claims of emigrants alone.

I respond to this blind spot by comparing how Liberians resident in Liberia and their transnational counterparts in West Africa, North America and Europe construe 'Liberian citizenship' ${ }^{1}$. Furthermore, I examine 'Liberian citizenship' construction through a historical prism, arguing that as Liberia transformed from a country of immigration to one of emigration, so too did conceptualisations of citizenship reconfigure across space and time. The empirical evidence presented in this article is based on multi-sited fieldwork conducted in 2012 and 2013 with 202 Liberians in Monrovia, Liberia's capital; Freetown, Sierra Leone; Accra, Ghana; Washington, DC, USA; and London, United Kingdom. Through interviews with homeland Liberians, permanent and circular returnees, Liberian diasporas, executive and legislative branch policy makers, I examine how their contemporary conceptualisations of 'Liberian citizenship' differ or cohere according to their lived experiences and social locations. I narrowed the spatial landscape of interview sites to capital cities given the growing body of literature on how certain

\footnotetext{
${ }^{1}$ Herein, I use inverted commas to encase the term 'Liberian citizenship' because it refers to the constantly shifting conceptualisations of citizenship over space and time.
} 
urban centres, particularly global cities such as London, New York and Tokyo, for instance, reproduce, refashion, and reconfigure identities, political engagement, and social practices (Sassen 1991; Isin 2000). I selected cities not only occupying different spheres of global influence, such as London and Washington, but also those with relatively sizeable Liberian populations, such as Monrovia, Freetown, and Accra, for a sub-regional comparison. The focus on cities was a deliberate attempt to hone in on how access to urban spaces shapes citizenship constructions amongst a range of Liberian social actors in Liberia and abroad.

In my conceptual framework, 'Liberian citizenship' is not only a bundle of rights and privileges embedded in constructions of legal, national and cultural identity, but it is also a set of practices and interactions embodied in the life-worlds of respondents in Liberia and across transnational spaces. Whereas contemporary constructions of identity-based 'Liberian citizenship' emphasise rights and entitlements, practice-based citizenship places a high premium on duties and responsibilities, and this is largely a function of Liberia's protracted armed conflict. Given the dynamic trends in citizenship configuration across the globe and particularly in Africa, this article fills gaps in the growing body of literature on citizenship and participation in emigrant-sending countries. It further contributes to wider debates about the reconfiguration of "identities and collective memories, and the relations between people and places...in the aftermath of violent conflict" (Malkki 1995, as quoted in Long 2001, 231) by exploring how historical and contemporary processes of conflict, migration, globalisation and post-war recovery have shaped 'Liberian citizenship' construction across space and time.

For instance, conflict manifested in direct and structural violence simultaneously ruptured and sealed state-citizen and citizen-citizen relations, thereby casting 'Liberian citizenship' as a space of contestation (Pailey 2014). Similarly, migration to and from Liberia in the $19^{\text {th }}, 20^{\text {th }}$ and $21^{\text {st }}$ centuries fundamentally altered the meaning of citizenship by creating categories of Liberians that defy the legal definition of citizen ${ }^{1}$. Moreover, globalisation fundamentally configured and reconfigured 'Liberian citizenship' through Liberia's adoption of human rights norms and regional protocols as well as its integration into the global capitalist system ${ }^{2}$. And the high stakes of post-war recovery in Liberia have galvanised increasing demands for not only active, practicebased citizenship, but also for the enactment of dual citizenship legislation, as reflected in the legal adoption of more cosmopolitan forms of citizenship in Africa and elsewhere (Spiro 1997; Rubenstein and Adler 2000; Manby 2009; Manby 2010; Pailey 2014). Thus, the conceptualisations of contemporary forms of 'Liberian citizenship' could serve as a model for theorising citizenship in post-war, and emigrant-sending contexts.

This article is divided into six constituent parts. Following this introduction is a brief review of the citizenship literature, where I present a conceptual framework of contemporary constructions of 'Liberian citizenship' that mirrors global trends expanding citizenship beyond the legal. The subsequent two sections illustrate briefly how 'Liberian citizenship' has been configured and reconfigured over space and time, largely precipitated by conflict, migration, globalisation and post-war recovery, and how a proposed dual citizenship bill is the outcome of that reconfiguration. I then employ 
empirical data to examine how Liberians in Liberia and abroad conceive of citizenship as passive, active and interactive. I conclude the article by presenting a visual representation of 'Liberian citizenship' as a triad representing identity (passive), practice (active) and a set of relations (interactive), making a case for why this conceptual framing could be adopted for post-war, emigrant country contexts and beyond.

\section{Beyond the Legal: Citizenship as a Continuum}

Citizenship has been construed over time to inscribe an individual within a particular polity, yet modern forms of citizenship transcend the nation-state, as reflected in the contemporary contestations over proposed dual citizenship legislation in Liberia. Similarly, although legal definitions often underpin the discourse on citizenshipwhether bounded or unbounded - emergent scholarship is beginning to define citizenship along sociological lines. Some scholars conceptualise citizenship as a social process whereby 'norms, practices, meanings and identities' are constantly negotiated by individuals and social groups, placing less of an emphasis on formal legal status with attendant rights and privileges in a territorial boundary (Isin 2000, 5). As a sociological construct, citizenship is relational; therefore the actual nature of state-citizen and citizencitizen relations supersedes legal constructions of how those interactions should be governed (van Steenbergen 1994, 2). Furthermore, a citizen is framed as 'a competent member of society' (Turner 1993, 2) who 'governs and is governed' by a set of practices (van Steenbergen 1994, 2). Expanding on this sociological model, Glick Schiller (2005) introduces the concept of social citizenship, which is inclusive of but broader than the definition of cultural citizenship. Social citizens, she argues, 'claim rights to citizenship through social practice rather than through the law' by making contributions to the state or demonstrating against discrimination within a state, for example (Glick Schiller 2005, $31)$.

In deconstructing citizenship, Sassen also argues that the narrow legal definition of citizenship does not adequately explain how citizens within a particular polity experience the institution differently, and how minority groups, though citizens, may not benefit from the social and political dividends of citizenship (Sassen 2005). In this vein, YuvalDavis $(2000,172)$ develops the notion of 'multi-layered citizenship' to describe how 'people's rights and obligations to a specific state are mediated and largely dependent on their membership of a specific ethnic, racial, religious or regional collectivity'. Although not entirely confined by it, 'people are not positioned equally within their collectivities' just as 'states are not positioned equally with other states' (Yuval-Davis 2000, 172). In essence, equal membership rights are not guaranteed by citizenship, legally defined only, prompting some excluded groups to subvert the institution of citizenship altogether, thereby claiming more rights and privileges (Sassen 2005). Newer forms of citizenship have emerged that transcend the legal, prompting some scholars to frame citizenship 'as both legal institution and lived experience' (Isin and Turner 2007, 16), as a form of political activity, identity and solidarity (Bosniak 2000, 451) and as an identification of group and individual engagement (Barry 2006, 20-21).

The various definitions of citizenship indicate that the term has stretched beyond its standard jus soli and jus sanguinis application, and certain conceptualisations resonate more strongly with scholars examining citizenship in multiple settings across the globe, 
including Liberia. In this article, 'Liberian citizenship' is simultaneously theorised in legal, political and sociological terms, based on qualitative interviews conducted with Liberians in Liberia and across transnational spaces. First, 'Liberian citizenship' is conceived of as passive and fixed, representing an identity anchored in legal status, cultural and national affiliation. Second, 'Liberian citizenship' is classified as active, representing a bundle of political and economic practices enacted by a multitude of actors. And third, 'Liberian citizenship' is categorised as interactive, represented by a set of relations between the Liberian state and its citizens in Liberia and abroad (state-citizen relations) and between Liberians across spatial landscapes (citizen-citizen relations) similar to the manner in which Fierke frames security as a set of relations between the protector and protected, the threatener and threatened (Fierke 2007). Furthermore, the assertion made by Brown $(2011,147,152)$ that citizenship is manifested in 'everyday encounters with the state' as political-legal relationships between states and their citizens, as well as 'affective [inter] personal relationships' between citizens, supports my conceptual framing of 'Liberian citizenship' as interactive.

In the next section, I present a historical analysis of how 'Liberian citizenship' has come to be understood as simultaneously passive, active and interactive.

\section{Configurations and Reconfigurations of 'Liberian Citizenship' across Space and Time}

From the beginning of Liberia's state formation, citizenship was conceived of as passive, active, and interactive, although early forms of citizenship were characterised by exclusion more than inclusion. Liberia's historical trajectory has been constituted by migration, mobility, conflict, exile and return, thereby facilitating new configurations of citizenship across space and time. The country was established in 1822 as an 'American outpost' of immigration for free blacks and repatriated slaves by the American Colonisation Society (ACS), an association of influential abolitionists, yet its history predates black settlement (Burrowes 2004, 1; Kieh 2012, 168). In 1847, Liberia declared itself independent seeking increased autonomy from the ACS, fearing British and French territorial encroachment (Guannu 1989, 49; Burrowes 2004, 61). During this time, the country became a prime location for the convergence of a multitude of disparate actors, including the 16 ethno-linguistic indigenous groups already occupying the territory, black repatriates from the United States, recaptives from the Congo River Basin in central Africa, and emigrants from the West Indies (Liebenow 1987, 19; Guannu 1989).

Despite its amalgam of identities, Liberia adopted a uniquely defined frame of citizenship that soon turned hegemonic (Burrowes 2004, 69). Modelled after the United States' initial conferring of citizenship on white male landed gentry, Liberia's construction of citizenship in the $19^{\text {th }}$ century reflected a settler male ethos, ruling out indigenes, nonChristians, women of both indigenous and settler orientation, and non-blacks (Burrowes 2004, 69). Not until 100 years after state formation would most Liberians of 'Negro descent' experience citizenship fully, when President William Tubman introduced the Unification Policy in 1946 subsequently recognising women and indigenous men as citizens for the first time in a decidedly failed attempt to construct a nation within a state (Wreh 1976, 42; Dunn 1979; Dunn, Beyan and Burrowes 2001, 341). 
Elite Liberians travelled to the United States and elsewhere for vacation, business ventures and higher education, but rarely did they remain outside of the country for long periods of time until Tubman's successor, William Tolbert, was assassinated in a 1980 coup (AHR 2009, 12). Rumoured to be an orchestrated plot by the US Central Intelligence Agency (CIA), the coup was led by a 25 -year-old indigenous master sergeant in the Armed Forces of Liberia (AFL), Samuel Kanyon Doe; it effectively toppled the TWP hegemony (Dunn 2009). Doe's military regime lasted until elections in 1985, which were largely viewed as fraudulent, entrenching his power in an arbitrary institutional arrangement (LCHR 1986, 118). For many, Doe's reign signified the beginning of an indigenous political renaissance because, among other reforms, he abrogated a 'hut tax' that tied citizenship to property ownership (Dunn, Beyan and Burrowes 2001, 170). Yet, his grip on power declined over time. When an attempted coup in November 1985 led by Thomas Quiwonkpa, one of Doe's trusted allies, was rumoured to have been supported by Liberians abroad, a wave of out-migration ensued with large numbers of Liberians leaving the country fearing reprisals (Dunn, Beyan and Burrowes 2001, 275). This effectively altered Liberia from a country of immigration to one of emigration. It also reconfigured 'Liberian citizenship,' making it transnational for the first time because large numbers of Liberians transformed into citizens from afar.

Liberian exiles in the United States, led by former Interim Government of National Unity (IGNU) President Amos Sawyer and current Liberian President Ellen Johnson Sirleaf, lobbied against Doe's authoritarian rule through the Association of Constitutional Democracy of Liberia (ACDL), but their cries for regime change fell on deaf ears (Huband 1998, 47). These political elites in large part would eventually support Charles Ghankay Taylor, a counter-revolutionary with political ambitions who trained in Libya and launched an armed rebellion in 1989 from neighbouring Ivory Coast, thereby prompting another wave of emigration and entrenching transnational citizenship norms (Gberie 2005; Sirleaf 2009; Waugh 2011). It is unclear how many Liberians returned to the country after elections in 1997 brought Taylor to power. From 1997 to 2003, he ruled with an iron fist, involving Liberia in Sierra Leone's armed conflict, thereby prompting two militia groups, the Movement for Democracy in Liberia (MODEL) and the Liberians United for Reconciliation and Democracy (LURD), to agitate between 1999 and 2003 for his ouster (Waugh 2011, 264-268; Hazen 2013, 105-110, 121, 131-133). Liberians once again emigrated for safety, followed by a Comprehensive Peace Agreement (CPA) in August 2003 in Accra, Ghana, with Taylor exiled at the invitation of the Nigerian government (Waugh 2011). On 26 April 2012, he was eventually convicted on 11 counts of war crimes and crimes against humanity for aiding and abetting rebels during Sierra Leone's war (Bowcott and Mark 2012).

From 2003 to 2005, an interim government was established to pave the way for elections in 2005 in which Africa's first female president, Sirleaf, was elected (GoL 2005). From 2003 onwards, waves of return migration to Liberia grew in magnitude and scale, with post-war recovery efforts eliciting renewed hope (GoL 2008a). Despite its multi-layered post-war challenges, Liberia has undergone transformation in Sirleaf's two successive terms, creating what some have argued has been an enabling environment for diasporic 
return and re-engagement. In $21^{\text {st }}$ century Liberia, the amalgam of different identities has somewhat metamorphosed, with homeland Liberians, returnees and diasporas making claims and counter-claims about citizenship and proposed dual citizenship.

\section{Proposed Dual Citizenship Legislation Reconstructs 'Liberian Citizenship'}

'Liberian citizenship' has been constructed and reconstructed since the founding of the nation-state in 1847, with current debates about proposed dual citizenship legislation serving as a contemporary manifestation of that reconfiguration over space and time. 'Liberian citizenship' has always been contested. As a case in point, there is a fundamental contradiction between Article 27 of Liberia's 1986 Constitution ${ }^{3}$, which states, 'All persons, who, on the coming into force of this Constitution, were lawfully citizens of Liberia shall continue to be Liberian citizens,' and Section 22.1 of its Aliens and Nationality Law, which automatically revokes the legal citizenship status of Liberiaborn nationals of 'Negro descent' who naturalise in, declare formal allegiance to, enter into the armed forces of, vote in the elections of, or formally renounce 'Liberian citizenship' in a foreign state (GoL 1973, 1986). Passed into law in 1973, and modelled after the 1952 US Immigration and Nationality Act, the Aliens and Nationality Law of Liberia has never been amended. Some have argued that it therefore fails to contend with contemporary configurations of 'Liberian citizenship' largely brokered by conflict, migration, globalisation, and post-war recovery (Pailey 2014).

For example, the current law states explicitly that only those of 'Negro'4 descent can be citizens and only those whose fathers were citizens of Liberia during the time of their birth and resided in Liberia before their birth can be granted citizenship at birth (GoL 1973). It also states that children of Liberian citizen parents must declare at the age of majority whether or not they claim legal 'Liberian citizenship' or the citizenship of the country in which they were born (GoL 1973). Therefore, the law distorts the principles of jus soli citizenship - citizenship by birth, regardless of race, ethnicity, or class - as well as jus sanguinis citizenship - citizenship by ancestry, regardless of parentage (ABA, 2009). The controversial reference to race as a defining marker of legal 'Liberian citizenship' remains contested and departs from more plural forms of citizenship, as do other markers such as citizenship traced through patrilineal lines alone (ABA, 2009). Some argue that revoking the citizenship of a natural born Liberian without due process is unconstitutional, as evidenced by the lawsuit filed in Liberia's Supreme Court in 2011 by US-based Liberian legal expert, Counsellor Alvin Teage Jalloh. ${ }^{5}$ Responding to increased pressure from what appears to be a strong transnational tide in Africa and elsewhere, Liberia introduced a dual citizenship bill in 2008 to reconstruct markers of citizenship.

In their proposed 'Act to Establish Dual Citizenship for Liberians by Birth and Background', four senators in Liberia's $52^{\text {nd }}$ Legislature-namely Cletus Segbe Wotorson, Sumo G. Kupee, Jewel Howard Taylor, and Abel Massalay-endorsed amendments to sections 20.1 and 22.1 of the Aliens and Nationality Law to conform to the current Constitution by enabling Liberian citizen women to pass on citizenship to their children and granting dual citizenship to Liberians by birth who naturalised abroad 
(or have aspirations to naturalise) as well as those born outside of Liberia to Liberian citizen parents, respectively (GoL 2008b). Though the bill recommends broad sweeping changes in an attempt to reconcile the (forced) migration of hundreds of thousands before, during, and after intermittent armed conflicts in Liberia, it has been postponed because, for some, naturalisation abroad signifies a rejection of the fundamental tenets of 'Liberian citizenship' as bounded by a single, geographical territory.

Using empirical evidence collected in five urban interview sites and employing the debates around proposed dual citizenship legislation as a backdrop, the following sections demonstrate that contemporary constructions of 'Liberian citizenship' transcend the 'birthplace' (jus soli) and 'bloodline' (jus sanguinis) principles.

\section{Birthplace, Bloodline and Beyond}

The introduction and postponement in passage of proposed dual citizenship legislation in Liberia is a manifestation of the ways in which 'Liberian citizenship' is constantly being negotiated and redefined. During an interview with me on 19 June 2013, then Minister of Justice Christiana Tah shared her reflections about the reconfiguration of 'Liberian citizenship' across space and time:

The definition [of 'Liberian citizenship'] has taken on new meanings. And because we went through this period of transformation during the war, it took on another meaning, too...It goes to the extent that it incorporates experiences. Shared experiences. And this is an informal definition, and it's a definition that just emerged from the war.

While 'Liberian citizenship' may have been construed as passive and constructed before armed conflict, newer meanings of citizenship are emerging to include more active forms of citizenship, bringing about the reconfiguration to which former Minister Tah alluded. Therefore, the conception of 'Liberian citizenship' amongst 202 Liberian respondents in London, Washington, Freetown, Accra, and Monrovia sits on a continuum between passivity and activity, identity and practice. The list in Table 1 illustrates recurring responses to an open-ended question posed to all respondents about how they defined a Liberian citizen, without prompts from a prescribed list.

Table 1: Top 10 conceptions of what constitutes a Liberian citizen amongst 202 respondents

\begin{tabular}{|l|l|}
\hline Markers of a Liberian Citizen & $\begin{array}{l}\text { Cities Where Responses Most } \\
\text { Frequent }\end{array}$ \\
\hline Born in Liberia (jus soli) & All \\
\hline Has Liberian mother or father (jus sanguinis) & All \\
\hline $\begin{array}{l}\text { Identifies as Liberian, feels and behaves Liberian } \\
\text { culturally (speaks Liberian language or Liberian }\end{array}$ & All \\
$\begin{array}{l}\text { English; dresses in Liberian clothing; eats Liberian } \\
\text { food) }\end{array}$ & \\
\hline Considers Liberia 'home' & London, Washington, Freetown, \\
\hline
\end{tabular}




\begin{tabular}{|l|l|}
\hline & Monrovia \\
\hline Raised in Liberia & London, Freetown, Monrovia \\
\hline Has 'heart', love or affinity for Liberia (and Liberians) & $\begin{array}{l}\text { London, Washington, Accra, } \\
\text { Monrovia }\end{array}$ \\
\hline $\begin{array}{l}\text { Has lived in Liberia extensively and/or currently } \\
\text { resides fulltime in Liberia }\end{array}$ & All \\
\hline Naturalises in Liberia & All \\
\hline $\begin{array}{l}\text { Shows allegiance, loyalty, and patriotism to Liberia } \\
\text { (and Liberians) }\end{array}$ & London, Freetown, Monrovia \\
\hline $\begin{array}{l}\text { Contributes to Liberia's development (involved in } \\
\text { capacity building and nation-building; abides by the } \\
\text { laws of Liberia and its Constitution; pays taxes; } \\
\text { invests in real estate and businesses; supports } \\
\text { democratic governance and peace; engages in political } \\
\text { processes) }\end{array}$ & \\
\hline
\end{tabular}

Although the markers of a Liberian citizen in the table are not ranked, the most prevalent responses were: 1) born in Liberia; 2) has a Liberian mother or father; 3) naturalises in Liberia; 4) has heart, love or affinity for Liberia; and 5) contributes to Liberia's development. The first five conceptions listed in the table of what constitutes a Liberian citizen are passive thereby constituting identity, whereas the last four are active thereby constituting practice. As one Monrovia-based circular returnee man informed me, being a Liberian citizen is 'a decision, and also an act. ${ }^{6}$ For instance, one who naturalises in Liberia expresses more active citizenship than someone who was merely born or raised in the country. The very act of naturalisation is agential, and involves making a conscious and deliberate choice to become a Liberian citizen. As the sixth item listed, 'having heart' for Liberia and Liberians straddles both the passive and active ends of the spectrum since feeling deeply committed to a nation and its people often compels one to act on behalf of that geographic territory and its citizens. The multiple meanings of 'Liberian citizenship' can thus be visualised as a continuum coupling passivity with identity and activity with practice. Whereas some respondents listed a single identity-based or practice-based criterion, such as 'born in Liberia' or 'contributes to Liberia's development', respectively, others listed multiple criteria from each end of the continuum. As illustrated in Table 1, Monrovia-based respondents in my study were most emphatic about multiple criteria for 'Liberian citizenship', with a composite list of markers that mostly surpasses those of respondents in the four diasporic field sites.

On the 'passive' side of the continuum, variants of the 'by birth' (jus soli) or 'by blood' (jus sanguinis) principles were invoked most often by respondents in the five urban interview sites. 'Birthplace' and 'bloodline' occupy the passive end of the spectrum because they generally require minimal to no effort, and are constituted by the conferral of automatic legal rights and privileges. When queried about who a Liberian citizen is, the majority of respondents conceptualised citizenship as a form of legal identity as enshrined in the Liberian Constitution and Aliens and Nationality Law. Yet, it is clear based on Liberia's cultural and social milieu that all those born in the country, regardless of their entitlements as 'Negroes', are not considered equal, just as Yuval-Davis (2000) 
argued that citizenship is 'multi-layered' and largely differentiated by socio-economic qualifiers. This is particularly stark for Liberians of the Mandingo ethnic group whose ancestors migrated from the Mali empire in the $14^{\text {th }}$ and $15^{\text {th }}$ centuries, establishing trade routes in slaves, gold, and kola nuts connecting the hinterland to the Atlantic coast (Konneh 1996a, 9, 56, 63; Konneh, 1996b, 142-143). Because of their constantly shifting trade and migratory patterns, faith in Islam, as well as cultural ties to several different West African countries, Mandingos have often been characterised as 'strangers' and therefore non-Liberian citizens (Konneh 1996a, 15, 25; Konneh, 1996b, 142, 144, 150). Their participation in Liberian economic and political life is further contested because they tend to dominate the public transport, retail and consumable goods sectors of the economy (Konneh 1996a, 135; Konneh, 1996b, 144, 151).

Konneh's assertion that Mandingos have always 'stood at the margins' of shifting conceptualisations of 'Liberian citizenship' (1996: 141) was echoed by a number of informants. Resident in London for 14 years, this 55-year-old female respondent with paternal roots in Guinea talked about the importance of maintaining the jus soli principle of citizenship, particularly for Liberia-born Mandingos:

I think [a] Liberian citizen is, I would say, those of us who grew up over there [Liberia]. Because we have had that problem, we as Mandingos in Liberia. People always say, "You Mandingo, you foreigner." But we say, "We were born here [Liberia]. We got just as much rights as, you know, as you people!"... Someone who was born in Liberia, I will consider them a citizen...

'Negroes' phenotypically, Mandingos pass the race-based requirement for legal 'Liberian citizenship', yet they are a stark example of how the birthplace principle in the Aliens and Nationality Law remains contested.

Roots, blood coursing through one's veins, and psychological attachments embody the existential entitlements of those who identify as Liberian citizens by ancestry, but who were not born in the country. For instance, a 59-year-old Washington-based respondent who had lived in the US for 31 consecutive years quipped about how her American-born daughter, who has never touched Liberian soil, understands the cultural logics of Liberian dress better than she does:

[My second-generation daughter] thinks she's a Liberian. You see that girl tie her lappa like one Kru woman and set that thing on her head. I was sitting here one time, the girl, when she was going to do her laundry, and she took the laundry basket and put it on her head...she just sat it on her head, it's just like it was something that was just in her. ${ }^{8}$

The idea that one's Liberianness can be inherited through biological and cultural transmission, regardless of birthplace, was echoed vigorously by other respondents in my study. For instance, a 65-year-old permanent returnee in Monrovia insisted that no one could negate the Liberianness of her American-born son, who had spent his childhood 
and adolescence in Liberia but returned to the US in adulthood to settle out of 'convenience",

Though the relevance of bloodline ties cannot be negated, some respondents argued that cultural links alone should not signify an automatic entitlement to 'Liberian citizenship' as legal status with attendant rights and privileges. For instance, a 49-year-old female respondent resident in the UK for 37 years argued that her UK-born children must earn the right to be considered Liberian citizens:

I wouldn't consider them [my children born in the UK] to be Liberian citizens... if they don't live in the country and they have never lived in the country I don't think it should be their automatic right because their parents are Liberians. ${ }^{10}$

This respondent was echoing the sentiments of many interviewees in Monrovia who ardently supported the provision within Liberia's Aliens and Nationality Law that someone of Liberian parentage must declare at the age of majority whether they want to maintain legal 'Liberian citizenship' or the citizenship of the country in which they were born.

Although there was contention about who should qualify for jus soli Liberian citizenship' and whether or not a statute of limitation should be placed on jus sanguinis citizenship, most respondents debunked the notion that citizenship should be traced only patrilineally and this was largely based on the post-war reconfiguration of gender norms in Liberia rather than on transnational forms of engagement or assimilation in the socalled Global North. This position was particularly salient for respondents who were born to Liberian citizen mothers/non-Liberian citizen fathers. As a case in point, one 43-yearold female resident in London for 22 consecutive years was born in the UK to a Liberian citizen mother. Although this respondent had lived in Liberia for half her life, having moved there before her first birthday, she complained about constantly having to defend her right to be called a Liberian citizen:

I say it's difficult because sometimes when I say to people, "Well, my father was a naturalised Liberian and I was born in the UK and, you know, and my maternal grandmother was actually Jamaican", they're like, "You're not Liberian!" and I'm like, "What gives you the right to say that, you know? Because I feel I am!" You know, I think I would define a Liberian citizen as someone who has some sort of ties, whether it's mother or father, to that country... a true Liberian is someone who identifies with that country and who accepts that they've got roots there. ${ }^{11}$

Since President Tubman's Unification Policy, which legally incorporated indigenous men and women and settler women who owned property as Liberian citizens, the notion that Liberian women should be relegated to the private sphere alone, without the attendant rights and privileges of citizenship, has been contested. As a case in point, the majority of male and female respondents in my study critiqued Liberia's constitutional provision 
barring a Liberian citizen woman from passing on citizenship to her children as overtly sexist and discriminatory.

\section{'Liberian Citizenship', Race and the 'Negro Clause'}

While there was consensus amongst interviewees about the need to enfranchise Liberian citizen women fully, those who voluntarily interrogated the 'Negro clause' were more ideologically divided, with their assessments based less on acknowledgment of pluralistic international conventions and more on lived experiences of non-black immigration to Liberia. While Monrovia-based respondents, particularly homelanders and dual citizenship bill sponsors alike, were more emphatic about maintaining the race-based proviso particularly because of the perceived contemporary socio-economic inequities between Lebanese, Indian, and Chinese merchants and resident Liberians, their counterparts abroad were either ambivalent or more inclined to reject the 'Negro clause.' Wide-ranging dissent about the 'Negro clause' is a function of historical and contemporary Asian and Middle Eastern immigration to Liberia. While Indian and Chinese migration to Liberia is relatively recent-with no empirical studies documenting this trend-Arab migration started in the early $20^{\text {th }}$ century and is therefore embedded in modern Liberian economic history (Dunn, Beyan and Burrowes, 2001, 203). Lebanese merchants, for instance, have historically dominated the retail industry in Liberia as owners of consumable goods, building materials and cement commercial chains across the country (Dunn, Beyan and Burrowes 2001, 203).

The most prevalent Arab emigrants in Liberia today are Lebanese nationals who cannot obtain citizenship because they are not 'of Negro descent.' A 30-year-old male homelander argued that the Lebanese, who have collectively resided in Liberia longer than Indian or Chinese migrants, are culturally differentiated by their own choice and therefore cannot be considered Liberian citizens:

Lebanese can never be Liberian by heart...In a sense that the Lebanese, they have customs and traditions...I don't care, the Lebanese can live here [Liberia], they can be born here, but their roots can never be forgotten. They can never forget their root. ${ }^{12}$

Taking an opposing view, a Monrovia-based circular returnee man argued that some individuals of non-Negro descent, such as Lebanese nationals, are politically and socially embedded in Liberia, contribute to economic productivity by virtue of their development practices, and should therefore be entitled to citizenship:

I'd consider them [Lebanese] to be Liberians, because I think they fulfil the conditions - living here, being part of the culture. They're part of the political discourse because they influence the political decisions that are made...In my definition, they are Liberians because any businesses they own pay taxes in Liberia. ${ }^{13}$ 
Deeply embedded in Liberia's historical DNA, the 'Negro clause' was instituted at a time when repatriated blacks had fled economic servitude in the United States vowing to create a haven for black people where they would be the sole owners of capital, land, and the means of production. While Liberians who currently support the clause espouse an identity-based frame of citizenship, arguing that 'non-Negroes' are too culturally and racially differentiated to be considered Liberians, those who oppose the clause adopt a practice-based frame of citizenship, arguing that 'non-Negroes' who actively participate in the economic life of the nation should be entitled to citizenship.

\section{'Liberian Citizenship' as 'Having Heart'}

Race and 'Liberian citizenship' are clearly entangled, yet unlike the first five markers of citizenship listed in the table at the beginning of this article that are passive and identitybased and therefore foregrounded by rights and privileges, the last four constitute practices that are active in orientation and therefore demand the fulfilment of duties and responsibilities. Connecting passivity with activity, the middle of the 'Liberian citizenship' continuum includes those who have the 'heart' for Liberia, as a 31-year-old London-based female respondent asserted:

...you do find people who are born in Liberia who don't have as much passion for Liberia compared to foreigners. I would say people who weren't born in Liberia but they found out about Liberia and they met Liberians and they've gone to the extent of investigating about Liberia and they've built that passion and do stuff for Liberia more than they do for themselves or their own country...if you've got the heart for Liberia you are a Liberian as well as those who are born there... ${ }^{14}$

The word 'heart' appeared as a recurring verbal motif in utterances from London to Washington, from Freetown to Accra, and within Monrovia, bringing us closer to what Barry and others call 'active citizenship' (Barry 2006) or citizenship as a 'public vocation' in which 'the (true) citizen plays a full and active part in the affairs of the community' (Dagger 2000, 27). For instance, a 30-year-old male homelander resident in Liberia all his life conceived of a Liberian by 'heart' as someone who prioritises Liberia's advancement above all other nations, regardless of one's citizenship or residence status:

When I talk about being a Liberian is by heart, it's that no matter the case, whether I have citizenship abroad, or whether I have citizenship in Liberia, but if I have Liberia at heart and I know that, yes, indeed, I am from Liberia, my root is from Liberia, all other development, all other improvement to make sure that Liberia improves, to make sure that Liberia be part of those nations that are up there, those expertise, those knowledge that I have, I should come and invest it in Liberia. That means I have Liberia at heart. ${ }^{15}$

This respondent echoed van Steenbergen $(1994,2)$, who defines the ideal citizen as 'active in public life and fundamentally willing to submit his [or her] private interests to 
the general interest of society'. Also employing the 'heart' trope was a 59-year-old woman resident in Accra on and off for 15 years, who argued that, '...for a person to be a Liberian [citizen], the person must have Liberia at heart. I mean, the person should be thinking development, thinking nation-building, human capacity... ${ }^{16}$ Similarly, a 36year-old female homelander in Monrovia equated 'heart' with jingoism and nationalist fervour, another common thread throughout my interviews: 'A Liberian [citizen] has a sense of patriotism, belonging to Liberia, and makes an effort to love his/her country thereby doing things that make Liberia progress or develop. ${ }^{17}$ Indeed, the articulation of 'Liberian citizenship' as 'having heart' is analogous to a feeling that induces action. 'Having heart' also appears to transcend the legal identity trope thereby eliminating birthplace, bloodline, and race as defining markers of Liberianness.

\section{'Liberian Citizenship' as 'Contribution'}

According to many respondents in the five urban sites, one who actively contributes to Liberia's development through political, economic and social practice-ie., voting in national elections, paying taxes, investing in real estate or local enterprise, sending remittances, developing Liberian capacities - demonstrates more active citizenship than one who merely identifies as Liberian or considers Liberia 'home.' A significant number of respondents conceived of 'Liberian citizenship' as a form of practice, essentially citizenship as 'doing' rather than 'being.' This brings us to the extreme end of the 'Liberian citizenship' continuum, narrowly defined as 'by contribution', in a multitude of frames. For instance, a 'Liberian is somebody who lives Liberia-not somebody who talks about Liberia" ${ }^{18}$, or someone who is 'prepared to give to Liberia, to serve Liberia, to be Liberia. ${ }^{19}$ On the extreme end of the 'contribution' spectrum is the notion that a Liberian citizen is 'one who is prepared to go to war for Liberia...prepared to take a bullet for Liberia... ${ }^{20}$ More practically, however, a 38-year-old male respondent based in Freetown for 12 years argued that personal and substantial investments in Liberia define a Liberian citizen, that if 'you are there and you have a very big institution that are contributing to the development of the country, I believe we should put hands around that person and make them a citizen of the country. ${ }^{, 21}$ A 34-year-old male resident in Accra for 12 years used more rhetorical language to describe how 'contribution' can be manifest in concrete action:

People must know that that country is the only thing we have, and must be willing to contribute. That is how I define a typical Liberian, contributing in any way possible to the society...Do you have family there, are you helping the family there? Do you have a home there? Can people really appreciate who you are? These are contributions... ${ }^{22}$

Most respondents who coupled 'citizenship' with 'contribution' argued that those contributions, however varied, should meaningfully impact Liberia and the lives of Liberians, wherever they happen to reside - essentially, 'Liberian citizenship' as a set of relations. One 38-year-old homeland woman even insisted that contributions should be unconditional, debunking claims by some diaspora respondents that their continued 
engagement with Liberia would be contingent on the passage of dual citizenship legislation:

A Liberian is somebody that is a true stakeholder... You know already that stakeholders are people that have interests, close interests to anything...I say this to say that I don't need to have X number of something or cash, or work before I know that I am a Liberian... ${ }^{23}$

Similarly, a 43-year-old male homeland development specialist insisted that unconditional commitment to Liberia should be a criterion for citizenship:

I think anyone who has a vested interest and commitment to seeing this country grow, whether it's economically, whether it's politically, whether it's culturally, whether it's socially, but demonstrates a high level of patriotism, you know, the love for a land, the love for a fellow compatriot...Anyone who is coming and saying, 'Look, I don't care whether I am offered a job in the government or a public agency, I just want to invest. I want the opportunity to contribute. 24

While some respondents argued that contribution to reconstruction and development should not be conditional, others, like one 48-year-old male homelander, maintained that 'Liberian citizenship' is bounded not only by residence in Liberia, but also by paying taxes regularly to the Liberian state:

First thing, it [citizenship] has to be tied to residency...Y You have to be here, you have to pay tax...That bounds you to the state-citizen responsibility, it's a part of the social contract...If you are a resident, you should have a vested interest...It could be in terms of your investment in businesses. Investment in just...property. Even investment in how you stay engaged with the country, in terms of even the political processes because all of those things add to who you are as a citizen... This is a community, so if you live in a community, there are roles and responsibilities, there are duties binding upon you to ensure that that community lives and fulfills its mandate...

By arguing that citizenship involves duties and responsibilities, this respondent implicitly described citizenship as a set of practices involving concrete contributions to state functionality. Although the respondent insisted that only residence could facilitate meaningful contribution, he conceded that residence could be sporadic and circular. Moreover, physical residence as a requirement for citizenship was not only advanced by homeland Liberians. An experienced media consultant who has been shuttling between the US and Liberia since 2006, one circular returnee respondent argued that 'what makes you a citizen of the country is to live, and make [a] decision to be there, to be part of that culture...Because you can't be in the US and say "I'm Liberian", not wanting to come home...So, you have to come home and be Liberian. ${ }^{26}$ I suspect that this respondent's resolve to return to Liberia was primarily informed by his conception of what signifies a 
'true Liberian citizen' - one who resides within the territorial confines of the nation-state, even if occasionally, and contributes to its development.

Nevertheless, the view that 'Liberian citizenship' is territorially configured, based on residence, and includes both rights and responsibilities represents a position not shared by all respondents in my study. For instance, a 56-year-old male Washington resident scorned the citizenship-as-residence trope, instead arguing that a Liberian citizen is 'anyone who dedicates his or her cause of life and everything to the Liberian cause...you cannot say because that person is not in the country, he is not a Liberian or she is not a Liberian. ${ }^{27}$ Some respondents, particularly those abroad, stressed their legal entitlements to 'Liberian citizenship' first, such as owning land, while only belatedly discussing obligations, such as paying property taxes, if at all. This has been corroborated by literature that critiques the discourse on dual citizenship as only about rights and privileges, rather than about duties and responsibilities (FitzGerald 2006, 2012, 285-286; Spiro 2012, 311, 318). One 58-year-old male respondent in Accra interrogated the tendency of Liberians to omit the 'responsibility' side of the citizenship equation altogether:

Let's ask ourselves, do we have citizenship only by name? Or you have citizenship based upon your responsibility and duty? If we say we are a Liberian, what are we doing for Liberia as a Liberian?...We cry [for] citizenship, we cry for rights, ok. Now, everything we find in this earth today, it has responsibility attached to it. ${ }^{28}$

Although most respondents in the five urban sites claimed that a Liberian citizen is someone who actively contributes to the country's development, interviewees in Freetown, Accra, and Monrovia were more explicitly wedded to this criterion. This could be attributed to the fact that resident citizens and 'near' diasporas (Van Hear 2009, 181), particularly those residing in countries in the so-called Global South such as Sierra Leone and Ghana, are closer in proximity to the challenges of development and therefore understand more intuitively the imperatives of active citizenship embodying duties and obligations. This trend was particularly apparent in the debates about whether or not citizenship should be based on residence. While most diasporic respondents dismissed residence in Liberia as a marker of citizenship, many homeland respondents, for instance, insisted that living in Liberia fulltime would be the only means of actively contributing to the political, economic and social life of the nation.

Just as the residence requirement appeared to be contested, so too was the citizenship by 'contribution' trope, proving that where 'Liberian citizenship' is concerned dissent is the only constant. Some respondents argued that 'Liberian citizenship' is solely about legal, cultural and national identity, and, by extension, rights and privileges, such as former Foreign Affairs Minister Augustine Ngafuan, who said on 11 June 2013: ‘... whether you contribute or not if you're a Liberian, you are Liberian. No one can take that citizenship from you.' However, Dr. C. William Allen, former Director-General of Liberia's Civil Service Agency (CSA) and now ambassador to France, countered this by providing on 4 June 2013 the most comprehensive articulation of the 'Liberian citizenship' continuum: 
Well, I think being a Liberian comes from what I call the Liberianness of a person. And, it's something like character. It's something that is on the inside of you. What do you feel in your soul? What do you feel in your inner self? Do you feel Liberian? And I think when you come to grips with that then the outward expression of your Liberianness is what makes you a Liberian [citizen]. Do you feel patriotic? Do you love your country? Do you honestly want to contribute towards its reform and its reconciliation and its development? Do you remain psychologically engaged with Liberia? If some other country were to attack Liberia tomorrow...would you be willing to give your time, treasure, and talent to the defence of Liberia? Ok, now, time, we all cannot serve in the military but could you provide advice? Treasure, meaning would you be willing to contribute to the national effort, resources, money, to help that effort? I think these are the real things that make you a Liberian [citizen]. It's not what colour of passport you wave around.

Allen's understanding of Liberianness as being manifested in contributions of 'time, talent, and treasure' couples identity with practice and rights with responsibilities, simultaneously. This particular frame is all-encompassing, thereby illustrating clearly the multi-layered meanings of 'Liberian citizenship' and how it has come to be reconfigured over space and time as identity, practice and a set of relations.

\section{Conclusion}

Because 'Liberian citizenship' has historically been a tool of exclusion-once barring women, non-settlers and non-Christians and still excluding non-blacks-it remains violently contested in Liberia and across transnational spaces, with often varied and contradictory constructions simultaneously cohering with and departing from a) how 'Liberian citizenship' is defined in legal terms and b) how citizenship is more generally theorised. I have demonstrated herein that while mid-to-late $19^{\text {th }}$ and early $20^{\text {th }}$ century 'Liberian citizenship' was understood as passive and constructed 'from above' by a hegemonic state, late $20^{\text {th }}$ and early $21^{\text {st }}$ century citizenship has been largely construed as active and reconstructed 'from below' by citizens themselves, primarily through processes of contestation.

In this vein, contemporary constructions of 'Liberian citizenship' transcend the legal definition enshrined in the country's 1973 Aliens and Nationality Law-moving from passive, identity-based citizenship to more active, practice-based citizenship-because of historical and contemporary processes of conflict, migration, globalisation and post-war recovery (Pailey 2014). According to the analysis in this article, Liberianness is anchored by the fluidity of jus soli and jus sanguinis principles of citizenship. Therefore, 'Liberian citizenship' remains contested primarily due to variances in the social locations and lifeworlds of Liberians within Liberia and across transnational spaces. This is also emblematic of a larger narrative of citizenship reconfiguration across the globe. 
Figure 1: 'Liberian citizenship' triad

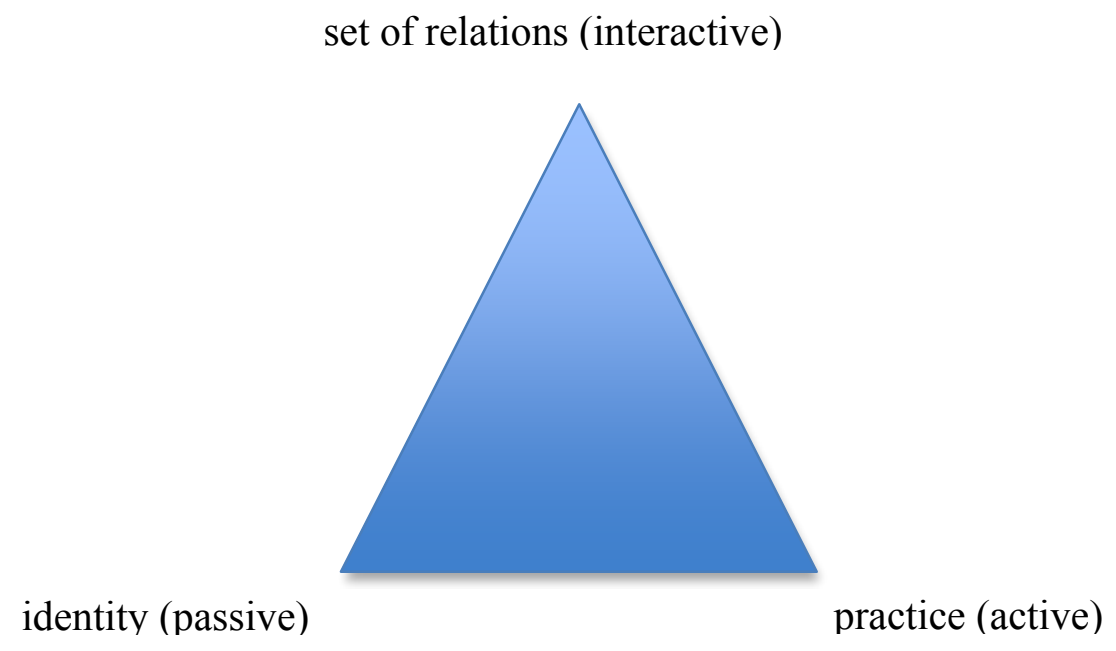

In the same way that Galtung (1996) formulated his conflict triangle, I conceptualise 'Liberian citizenship' as a set of three axes that could be used as a model for reconciling the competing theoretical understandings of citizenship as defined in the academic literature. As Figure 1 illustrates, my conceptualisation of 'Liberian citizenship' as identity (passive), practice (active), and a set of relations (interactive) encompasses political, legal, sociological and cultural constructions of citizenship, thereby representing a holistic realisation of the term. For instance, 'Liberian citizenship' as identity is passive and fixed, largely anchored by legal status. As practice, 'Liberian citizenship' represents a series of economic and political activities such as investing in real estate and voting in national elections. And as a set of relations, 'Liberian citizenship' signifies how Liberian citizens interact with each other as social beings and with the post-war state as political beings.

Each point on the 'Liberian citizenship' triad responds to how citizenship is defined in the literature, and it can be applied in post-war, emigrant sending contexts, or more broadly in other contexts. The model includes multiple levels of conceptualisationmoving from the individual to how the individual interacts with his/her state and society. It reconciles contestations about whether or not citizenship is bounded or unbounded because it does not include spatial categories of differentiation. Furthermore, my 'Liberian citizenship' triad is informed by empirical research about a country of emigration and a site where post-war reconfigurations of identities and relationships are enacted. This visual representation transcends the often-siloed interpretations of citizenship, and reinforces Malkki's argument that identities, practices and relations between people change as a result of violent conflict. Therefore, the triad is representative of the configuration and reconfiguration of 'Liberian citizenship' across space and time, while also illustrating that these disputed understandings are relational and can co-exist in the same conceptual plane. 


\section{References}

ABA (American Bar Association). 2009. "Analysis of the Aliens \& Nationality Law of the Republic of Liberia." Washington, D.C.: American Bar Association.

AHR (Advocates for Human Rights). 2009. The House with Two Rooms: Final Report of the Truth and Reconciliation Commission of Liberia Diaspora Project. Saint Paul, Minnesota: Dispute Resolution Institute Press.

Barry, Kim. 2006. "Home and Away: The Construction of Citizenship in an Emigration Context." New York University Public Law and Legal Theory Working Papers Review 81: 11-59.

Bosniak, Linda. 2000. “Citizenship Denationalised.” Indiana Journal of Global Legal Studies 7 (2): 447-509.

Bowcott, Owen and Monica Mark. 2012. "Charles Taylor Found Guilty of Abetting Sierra Leone War Crimes." The Guardian (UK), 26 April. http://www.theguardian.com/world/2012/apr/26/charles-taylor-guilty-war-crimes

Brown, Hana E. 2011. "Refugees, Rights and Race: How Legal Status Shapes Liberian Immigrants' Relationship with the State." Social Problems 58 (1): 144-163.

Burrowes, Carl Patrick. 2004. Power \& Press Freedom in Liberia, 1830-1970. Trenton: African World Press.

Dagger, Richard. 2000. "Metropolis, Memory and Citizenship." In Democracy, Citizenship and the Global City, edited by Engin F. Isin, 25-47. London: Routledge.

Dunn, D. Elwood. 1979. The Foreign Policy of Liberia during the Tubman Era 19441971. London: Hutchinson Benham. -2009. Liberia and the United States During the Cold War: Limits of Reciprocity. New York: Palgrave MacMillan.

Dunn, D. Elwood, Amos J. Beyan, and Carl Patrick Burrowes. 2001. Historical Dictionary of Liberia: Second Edition. Lanham and London: The Scarecrow Press.

Fierke, Karin M. 2007. Critical Approaches to International Security. Cambridge, UK and Malden, Massachusetts: Polity Press.

FitzGerald, David. 2006. "Rethinking Emigrant Citizenship.” New York University Law Review 81 (90): 90-116.

-2012. "Citizenship a La Carte: Emigration and the Strengthening of the Sovereign State." In Politics from Afar: Transnational Diasporas and Networks, edited by Terrence Lyons and Peter Mandaville, 197-212. London: Hurst. 
Galtung, Johan. 1996. Peace by Peaceful Means: Peace and Conflict, Development and Civilisation. London: Sage.

Gberie, Lansana. 2005. "Liberia's War and Peace Process: A Historical Overview." In $A$ Torturous Road to Peace: The Dynamics of Regional, UN, and International Humanitarian Interventions in Liberia, edited by Festus B. Aboagye and Alhaji MS Bah, 51-71. Pretoria: Institute for Security Studies.

Glick Schiller, Nina. 2005. "Transborder Citizenship: An Outcome of Legal Pluralism within Transnational Social Fields." In Mobile People, Mobile Law: Expanding Legal Relations in a Contracting World, edited by F. B. Beckman, K. B. Beckman and A. Griffiths, 48-90. London: Ashgate.

GoL (Government of Liberia). 1973. Aliens and Nationality Law of Liberia. Monrovia: Government of the Republic of Liberia.

1986. Constitution of the Republic of Liberia, Republic of Liberia. Monrovia: Government of the Republic of Liberia. -2005. “2005 Election Results/By-Election Results.” Monrovia: National Elections Commission of Liberia. http:/www.necliberia.org/results/ -2008a. Liberia Poverty Reduction Strategy. Monrovia: Government of the Republic of the Liberia. 2008b. “A Proposed Act to Establish Dual Citizenship for Liberians By Birth and Background.” Monrovia: Senate, Republic of Liberia.

Guannu, Joseph Saye. 1989. A Short History of the First Liberian Republic. Pompano Beach: Exposition Press of Florida.

Hazen, Jennifer M. 2013. What Rebels Want: Resources and Supply Networks in Wartime. Ithaca: Cornell University Press.

Huband, Mark. 1998. The Liberian Civil War. London: Frank Cass Publishers.

Isin, Engin F. 2000. "Introduction: Democracy, Citizenship and the City." In Democracy, Citizenship and the Global City, edited by Engin F. Isin. London: Routledge: 1-21.

Isin, Engin F. and Turner, Bryan S. 2007. "Investigating Citizenship: An Agenda for Citizenship Studies.” Citizenship Studies 11 (1): 5-17.

Kieh, George Klay Jr. 2012. "Neo-Colonialism: American Foreign Policy and the First Liberian Civil War.” Journal of Pan-African Studies 5 (1): 164-184.

Konneh, Augustine. 1996a. Religion, Commerce, and the Integration of the Mandingo in Liberia. Lanham: University Press of America.

-1996b. "Citizenship at the Margins: Status, Ambiguity, and the Mandingo of 
Liberia." African Studies Review 39 (2): 141-154.

LCHR (Lawyers Committee for Human Rights). 1986. Liberia: A Promise Betrayed. New York: Lawyers Committee for Human Rights.

Liebenow, Gus. 1987. Liberia: The Quest for Democracy. Bloomington: Indiana University Press.

Long, Norman. 2001. Development Sociology: Actor Perspectives. New York: Routledge.

Malkki, Liisa. 1995. Purity and Exile: Violence, Memory, and National Cosmology among Hutu Refugees in Tanzania. Chicago: University of Chicago Press.

Manby, Bronwen. 2009. Struggles for Citizenship in Africa. London and New York: Zed Books.

---------2010. "Citizenship Law in Africa: A Comparative Study.” New York and Johannesburg: Open Society Foundations, AfriMap, and Open Society Justice Initiative.

Pailey, Robtel Neajai. 2014. "The Love of Liberty Divided Us Here? Factors Leading to the Introduction and Postponement in Passage of Liberia's Dual Citizenship Bill." $\mathrm{PhD}$ thesis, SOAS, University of London.

Rubenstein, Kim and Adler, Daniel. 2000. "International Citizenship: The Future of Nationality in a Globalised World." Indiana Journal of Global Legal Studies 7 (2): 519-548.

Sassen, Saskia. 1991. The Global City: New York, London, Tokyo. Princeton: Princeton University Press. -2005. "The Repositioning of Citizenship and Alienage: Emergent Subjects and Spaces for Politics." Globalisations 2 (1): 79-94.

Sirleaf, Ellen Johnson. 2009. This Child Will Be Great: Memoir of a Remarkable Life by Africa's First Woman President. New York: Harper Collins.

Spiro, Peter. 1997. "Dual Nationality and the Meaning of Citizenship." Emory Law Journal 46 (4): 1412-1485.

-------2012. "Citizenship and Diaspora: A State Home for Transnational Politics?" In Politics from Afar: Transnational Diasporas and Networks, edited by Terrence Lyons and Peter Mandaville, 213-227. London: Hurst.

Turner, Bryan S. (1993). "Contemporary Problems in the Theory of Citizenship." In Citizenship and Social Theory, edited by Bryan S. Turner. London: Palgrave: 1-18.

Van Hear, Nicholas. 2009. "The Rise of Refugee Diasporas." Current History 108 
(717): 180-185.

van Steenbergen, Bart. 1994. “The Condition of Citizenship: An Introduction.” In The Condition of Citizenship, edited by Bart van Steenbergen, 1-9. London: Sage Publications.

Waugh, Colin. 2011. Charles Taylor and Liberia: Ambition and Atrocity in Africa's Lone Star State. New York and London: Zed Books.

Wreh, Tuan. 1976. The Love of Liberty... The Rule of President William V.S. Tubman in Liberia 1944-1971. London: C. Hurst \& Company.

Yuval-Davis, Nira. 2000. "Citizenship, Territoriality and the Gendered Construction of Difference." In Democracy, Citizenship and the Global City, edited by Engin F. Isin, 171-188. London: Routledge.

\section{Acknowledgments}

This article is an excerpt of my unpublished $\mathrm{PhD}$ thesis entitled "The Love of Liberty Divided Us Here? Factors Leading to the Introduction and Postponement in Passage of Liberia's Dual Citizenship Legislation." Research was conducted at SOAS, University of London. I am grateful to the Mo Ibrahim Foundation (MIF) for their financial support, Dr. Laura Hammond for her supervision, as well as the 202 Liberian respondents who welcomed me into their lives and entrusted me with their stories. I would also like to thank the editors of Citizenship Studies and the two anonymous reviewers for comments on initial drafts of this article.

\footnotetext{
${ }^{1}$ Ibid.

${ }^{2}$ Ibid.

${ }^{3}$ Although Liberia's Constitution was amended in 1986 as part of a post-election constitutional review process, the reviewers neglected to reconcile the apparent contradictions between the Constitution and the Aliens and Nationality Law on matters of citizenship. In 2012, President Sirleaf commissioned a Constitution Review Committee to review and make recommendations for amending the 1986 Constitution, based on a series of national consultations with Liberian citizens.
}

\footnotetext{
${ }^{4}$ To date, Liberia and Sierra Leone are the only two countries in Africa that explicitly define citizenship by 'Negro' descent, although Sierra Leone's 2006 Dual Citizenship Act enables 'non-Negroes' to naturalise.
} 
${ }^{5}$ Jalloh's case is not in pursuit of dual citizenship, per se, but rather a lawsuit interrogating sections 22.1 and 22.2 of Liberia's Aliens and Nationality Law, which, he argues, violates Article 20 of the Liberian Constitution guaranteeing due process.

${ }^{6}$ [CR7] Interview in Monrovia on June 18, 2013.

${ }^{7}$ [DL9] Interview in London on June 13, 2012.

${ }^{8}$ [DL56] Interview in Washington on October 26, 2012.

${ }^{9}$ [PR6] Interview in Monrovia on June 24, 2013.

${ }^{10}$ [DL6] Interview in London on June 12, 2012.

${ }^{11}$ [DL15] Interview in London on June 15, 2012.

${ }^{12}$ [HL17] Interview in Monrovia on June 12, 2013.

${ }^{13}$ [CR7] Interview in Monrovia on June 18, 2013.

14 [DL3] Interview in London on June 9, 2012.

${ }^{15}$ [HL17] Interview in Monrovia on June 12, 2013.

16 [DL83] Interview in Accra on May 7, 2013.

${ }^{17}$ [HL7] Interview in Monrovia on June 6, 2013. 
${ }^{18}$ [CR7] Interview in Monrovia on June 18, 2013.

${ }^{19}$ [PR1] Interview in Monrovia on June 7, 2013.

${ }^{20}$ [PR3] Interview in Monrovia on June 11, 2013.

${ }^{21}$ [DL62] Interview in Freetown on April 11, 2013.

22 [DL105] Interview in Accra on May 20, 2013.

${ }^{23}$ [HL24] Interview in Monrovia on June 17, 2013.

${ }^{24}$ [HL3] Interview in Monrovia on June 5, 2013.

${ }^{25}$ [HL45] Interview in Monrovia on June 24, 2013.

${ }^{26}$ [CR7] Interview in Monrovia on June 18, 2013.

${ }^{27}$ [DL52] Interview in Washington on October 25, 2012.

${ }^{28}$ [DL101] Interview in Accra on May 19, 2013. 